\title{
Prospective tourist preferences for sustainable tourism development in Small Island Developing States
}

\author{
Gaetano Grilli ${ }^{\text {a,c, }}$, Emmanouil Tyllianakis ${ }^{\text {b,c }}$, Tiziana Luisetti ${ }^{\text {, }}$, Silvia Ferrini ${ }^{\text {a,d }}$, \\ R. Kerry Turner ${ }^{a}$ \\ ${ }^{a}$ Centre for Social and Economic Research on the Global Environment, School of Environmental Sciences, University of East Anglia, NR4 7TJ, UK \\ ${ }^{\mathrm{b}}$ Sustainability Research Institute, University of Leeds, LS2 9JT, UK \\ ${ }^{\mathrm{c}}$ Centre for Environment, Fisheries and Aquaculture Science, NR33 OHT, UK \\ ${ }^{\mathrm{d}}$ Department of Political and International Sciences, University of Siena, Via P.A. Mattioli 10, 53100, Siena, Italy
}

\section{A R T I C L E I N F O}

\section{Keywords:}

Sustainable tourism

Small islands developing states

Latent factor analysis

Choice experiment

Ecosystem services

\begin{abstract}
A B S T R A C T
Tourism development is crucial for economic growth in Small Island Developing States, but its management involves trade-offs between ecosystem services and social and cultural identities. This paper aims to contribute to the debate around the achievement of the Sustainable Development Goals through an investigation of the sustainable management of tourism and coastal ecosystem services. The paper presents a choice experiment and latent factor analysis to disentangle relevant aspects of sustainable tourism in Small Island Developing States for potential visitors. Willingness to pay is reported for the different factors revealing preferences variability for previous and prospective visitors. Pro-environmental attitudes influence individual tastes and policy makers should consider these traits in order to attract visitors and private funding. Our findings show that prospective tourists are interested in the wider aspects of the tourism experience which in turn require the careful management of social and environmental resources in Small Island Developing States.
\end{abstract}

\section{Introduction}

Distinct cultural heritage and a unique natural environment are some of the comparative advantages of Small Island Developing States (SIDS), which attract large numbers of visitors every year (UNWTO, 2012; 2020). Having recognised the potential contribution of tourism to economic growth and employment generation, and due to limited opportunities for economic diversification, SIDS communities have tried to encourage tourism as a development alternative (Bojanic \& Lo, 2016; Pratt, 2015; Schubert et al., 2011; Seetanah, 2011). However, the negative social and environmental effects of the tourism industry have been increasingly recognised (Buckley, 2012; Gössling, 2002; Neto, 2003; Pan et al., 2018). Habitat loss in SIDS coastal areas due to tourism development is a major threat for mangroves, estuaries, reefs and foreshore ecosystems (Bernard \& Cook, 2015). In addition, if on the one side, tourism can positively influence the socio-cultural context in host countries for example through hosts-guests interaction (Das \& Chatterjee, 2015), on the other side it can threaten heritage, cultural identity and wellbeing (Coria \& Calfucura, 2012; Pan et al., 2018; Pratt et al.,
2016; Sharpley, 2014; Woo et al., 2015). Efforts to promote the sustainability of the tourism sector have long been advocated in policy and research circles (UNWTO, 2017; Buckley, 2012; UNWTO, 2012). Despite SIDS vulnerability to environmental and economic shocks (Scandurra et al., 2018) and their often over-reliance on tourism (Schubert et al., 2011; Narayan, 2010), this sector, when sustainably managed, has the potential to make a significant contribution towards the achievement of a range of Sustainable Development Goals (SDGs) (UN, 2015). Sustainable tourism, for example, could be part of a national strategy to conserve SIDS marine and terrestrial habitats and biodiversity (SDGs 14 and 15), particularly the iconic coral reefs. It could also promote more resilient urban planning, while safeguarding cultural and national heritage (SDG 11). Policies that promote sustainable tourism may in turn create new jobs (SDG 8) and help reduce inequalities (SDG 10). Sustainable tourism should therefore be seen as an opportunity for SIDS to enhance their economic growth, but also provide biodiversity protection, and promote and conserve local culture.

Nonetheless, a strategy to promote more sustainable tourism development faces several challenges and will involve complex economic,

\footnotetext{
* Corresponding author. Centre for Social and Economic Research on the Global Environment, School of Environmental Sciences, University of East Anglia, NR4 7TJ, UK.

E-mail address: G.Grilli@uea.ac.uk (G. Grilli).
} 
environmental and social policy trade-offs (UNWTO, 2012; Pan et al., 2018). Moreover, increased financial aid to support this process is needed, especially in SIDS and developing countries. This increase may take the form of Official Development Assistance (ODA), a country-to-country transfer of funds, or private investments and expenditures. Therefore, if tourism sustainability targets are to be achieved, an evidence base, which includes information on the existence and magnitude of the values and positive preferences of potential prospective tourists, is an important pre-requisite to enable policy processes.

Research on preferences and values for sustainable tourism development in remote areas by prospective tourists has been limited, and widely focused on biodiversity and ecosystems conservation (e.g., Morse-Jones et al., 2012; Navrud \& Strand, 2018; Rolfe et al., 2000). Studies that systematically assess the trade-offs between environment, cultural heritage and tourism management options are rare and missing for SIDS. Accordingly, the main objective of this research is to fill this gap in the literature and measure the latent factors and willingness-to-pay (WTP) for sustainable tourism development in SIDS by prospective tourists, with a focus on coastal and marine ecosystems. Our case study focuses on Fiji because this is one of the most tourism-dependent SIDS in the world (Narayan et al., 2010). We developed and remotely administered a survey to a sample of UK residents. The survey included a choice experiment (CE) and attitudinal and behavioural questions to reveal the preferences and WTP trade-offs. The key feature of our CE is to systematically account for habitats protection, cultural values preservation, and tourism industry management. At the same time, the analysis of attitudinal and preference questions describes the main traits of prospective visitors, revealing respondents' preferences, past experience, environmental beliefs, ecotourism attitudes, pro-environmental behaviours and how these are potentially interlinked. Methodologically, we jointly model choice experiment and latent factor data and provide a more comprehensive understanding of the challenges and opportunities related to sustainable development strategies for SIDS. The paper has three main aims: $(i)$ determine the value attached to sustainable tourism initiatives in remote destinations, such as SIDS, (ii) disentangle the trade-offs between sustainability dimensions (environmental, economic and social), and (iii) assess the influence of latent factors (individual experience, attitudes and beliefs) that characterise the potential visitors' preferences.

The results are particularly relevant to gaining a better understanding of how sustainable tourisms can help in the attainment of the SDGs and how policy decision makers can prioritize resources to restore and maintain iconic habitats (SDGs 14,15), heritage and cultural identity (SDGs 10,11 ), and promote a more sustainable tourism industry (SDGs $8,10)$.

\section{Background}

United Nations Environment Programme and World Tourism Organization(2005) define sustainable tourism as "Tourism that takes full account of its current and future economic, social and environmental impacts, addressing the needs of visitors, the industry, the environment and host communities". Tourism sustainability has long been debated by policymakers and practitioners (UNWTO, 1997; Buckley, 2012; Ruhanen et al., 2015). However, it is during the last two decades that policy and practical initiatives have proliferated globally, and that the crucial role of tourism in sustainable development has been fully acknowledged (UNWTO, 2017). Nowadays, sustainability in tourism is a paradigm characterising the future of the sector and is reflected in a variety of practices such as ecotourism, nature-based tourism, heritage tourism, community tourism, and rural tourism (Pan et al., 2018).

Similarly, public policy interest in the strong tie between tourism and sustainable growth in SIDS has only recently gained international prominence in the light of increasing concerns over their vulnerability (UNWTO, 2012). This debate has been further promoted through the
SIDS Accelerated Modalities of Action (SAMOA) Pathway agreement $((U N, 2014))^{1}$ resulting in several initiatives. In the Pacific area, for example, the recognition of the benefits stemming from local communities' involvement in natural resources management has led to the creation of several Community Conserved Areas and Locally Managed Marine Areas (Govan et al., 2009). In Fiji, experiences of community-based environmental management evolved in Marine Conservation Agreements between tourism operators and local communities, aimed at preserving biodiversity and cultural heritage, whilst providing revenues and employment opportunities (Mangubhai et al., 2020). However, the success of sustainable tourism initiatives in SIDS critically depends on the availability of financing schemes, including international official development assistance funds and foreign direct investments. International financing has played a central role in supporting sustainable development and tourism in SIDS (United Nations Development Programme, 2015; Witter, 2011; Barrowclough, 2007; Craigwell \& Moore, 2008). However, resources for development funding have been consistently shrinking (UNEP, 2014). Therefore, decision makers need to tackle two issues: explore new financing mechanisms and potential markets, and be more efficient in allocating the scarce resources to protect the local economy, society and the fragile environment.

Evidence on the preferences of potential visitors and donors could support decision makers in this task. Stated preferences methods, particularly CEs, have been specifically applied to determine tourists' preferences towards nature-based ecotourism, and sustainable tourism development in developing countries. However, only a few studies explored the values that prospective tourists place on sustainable tourism development and ecosystem services protection in the context of remote areas (Morse-Jones et al., 2012; Swanson \& Kontoleon, 2004; Kontoleon \& Swanson, 2003; Kramer \& Mercer, 1997; Rolfe et al., 2000; Svedsäter, 2000; Horton et al., 2003; Navrud \& Strand, 2018; Huybers \& Bennett, 2000). Moreover, there is a lack of studies that take a holistic perspective on tourism sustainability by explicitly addressing the trade-offs between environmental, cultural, and industry-related aspects. Table 1 provides a summary of the relevant published literature.

In the past few years, a growing literature has focused on the estimation of models combining unobserved factors, such as motivations, experience, attitudes, and beliefs, with observed components of individual utility (e.g. Hess \& Beharry-Borg, 2012). This combined approach allows for the estimation of WTP for goods and services while examining the effect that those unobserved factors might have on it. There are studies focusing on the link between pro-environmental attitudes and WTP for protecting endangered species (Choi \& Fielding, 2013; Grilli et al., 2018); on improved water quality (Cooper et al., 2004; Hess \& Beharry-Borg, 2012; Pakalniete et al., 2017); on engagement in eco-friendly travel modes (Hultman et al., 2015); on land-use policies in Natura 2000 sites (Hoyos et al., 2015); and on recreational park selection (Boxall \& Adamowicz, 2002).

This paper aims to expand on this literature and provide novel evidence on tourist preferences for the different aspects of sustainable tourism development in SIDS. The empirical assessment focuses on the drivers of preferences, WTP, and trade-offs that prospective visitors hold for environmental, cultural, and industry-related sustainability. The aim is to gain an increased understanding of how tourism contributes towards sustainable development and SDGs. Improved evidence of the

\footnotetext{
1 The SAMOA Pathway is a SIDS-targeted sustainable development plan adopted following the third International Conference on Small Island Developing States held in Samoa in 2014. The pathway explicitly mentions tourism as one of the most important sectors for achieving sustainable growth in SIDS. The relevance of the international policy debate on SIDS sustainable development and tourism is also highlighted by the designation of the International Year of Small Island Developing States in 2014 and the International Year of Sustainable Tourism for Development in 2017.
} 
Table 1

Overview of stated preference studies on sustainable tourism.

\begin{tabular}{|c|c|c|c|c|c|c|}
\hline Study & Environmental sustainability & Cultural sustainability & Industry sustainability & SIDS & Visitors type & Method $^{\mathrm{a}}$ \\
\hline Kramer and Mercer (1997) & $\checkmark$ & & & No & Remote & $\mathrm{CV}$ \\
\hline Huybers \& Bennett, 2000 & $\checkmark$ & & $\checkmark$ & No & Remote & $\mathrm{CE}$ \\
\hline Rolfe et al. (2000) & $\checkmark$ & $\checkmark$ & & Yes & Remote & $\mathrm{CE}$ \\
\hline Svedsäter (2000) & $\checkmark$ & & & No & Remote & $\mathrm{CV}$ \\
\hline Hong et al. (2003) & & & $\checkmark$ & No & Actual & $\mathrm{CE}$ \\
\hline Kontoleon and Swanson (2003) & $\checkmark$ & & & No & Remote & CV \\
\hline Horton et al. (2003) & $\checkmark$ & & & No & Remote & $\mathrm{CV}$ \\
\hline Swanson and Kontoleon (2004) & $\checkmark$ & & & No & Remote & CV \\
\hline Alexandros and Jaffry (2005) & & $\checkmark$ & & No & Actual & $\mathrm{CE}$ \\
\hline Hearne and Santos (2005) & $\checkmark$ & & $\checkmark$ & No & Actual & $\mathrm{CE}$ \\
\hline Naidoo and Adamowicz (2005) & $\checkmark$ & & $\checkmark$ & No & Actual & $\mathrm{CE}$ \\
\hline Kelly et al. (2007) & & & $\checkmark$ & No & Actual & $\mathrm{CE}$ \\
\hline Kim et al. (2007) & & $\checkmark$ & & No & Actual & CV \\
\hline Edwards (2009) & $\checkmark$ & & & Yes & Actual & CV \\
\hline Choi et al. (2010) & & $\checkmark$ & & No & Actual & $\mathrm{CE}$ \\
\hline Chaminuka et al. (2012) & & $\checkmark$ & $\checkmark$ & No & Actual & $\mathrm{CE}$ \\
\hline Morse-Jones et al. (2012) & $\checkmark$ & & & No & Remote & $\mathrm{CE}$ \\
\hline Lee \& Du Preez, 2016 & $\checkmark$ & & & No & Actual & $\mathrm{CE}$ \\
\hline León et al. (2015) & $\checkmark$ & & $\checkmark$ & No & Actual & $\mathrm{CE}$ \\
\hline Chen et al. (2017) & $\checkmark$ & $\checkmark$ & & No & Actual & $\mathrm{CV}$ \\
\hline Navrud and Strand (2018) & $\checkmark$ & & & No & Remote & CV \\
\hline Iranah et al. (2018) & $\checkmark$ & & & Yes & Actual & $\mathrm{CV}$ \\
\hline
\end{tabular}

${ }^{a} \mathrm{CV}$ : contingent valuation; CE: choice experiment.

trade-offs between the dimensions of tourism sustainability can help policy makers and the wider tourism industry to shape policies and initiatives that meet the needs and preferences of established and new market segments. The value attached by prospective tourists to sustainable tourism in remote areas can guide the assessment of financial schemes and resources needed to support a sustainable and equitable development path.

\section{Materials and methods}

The survey was designed to accommodate attitudinal and behavioural questions and the CE. Each method reveals part of respondents' preferences. CE can determine the marginal willingness to pay for different aspects of tourism options, and attitudinal and behavioural questions can describe latent factors of respondents' preferences.

\subsection{Attitudinal and behavioural questions: latent factors}

In the survey questionnaire, respondents were presented with 17 attitudinal and behavioural Likert-type statements aimed at describing three latent factors: Eco-tourism attitudes, Pro-environmental private behaviour, and Environmental beliefs (Table 2).

Eco-tourism attitudes are described using six statements adapted from Castellanos-Verdugo et al. (2016). People with those attitudes are expected to target tourism destinations which apply sustainable practices in their accommodation and amenities' management (Chen \& Tung, 2014). Pro-environmental private behaviour attitudes are described through six statements adapted from Kaiser and Wilson (2004) and can be used to explain intentions to visit sustainably managed tourism destinations. These attitudes have been viewed as good predictors of "environmental activism" (e.g. activities such as donating to environmental organisations) (Dono et al., 2010). In the literature, it has also been found that individuals with strong Environmental beliefs act in a more environmentally friendly manner. We identify them by using five of the New Environmental Paradigm statements found in Hultman et al. (2015) and adapted from Dunlap and Van Liere (1978) and Dunlap et al. (2000).

\subsection{Choice experiment}

In CEs, respondents are presented with a set of choice situations and
Table 2

Latent factors and related set of statements presented in the survey questionnaire.

\begin{tabular}{|c|c|c|}
\hline Latent factor & Variable & Statement \\
\hline \multirow[t]{6}{*}{ Eco-tourism attitudes } & lf_avoid & $\begin{array}{l}\text { Tourism in sustainably managed tourist } \\
\text { areas should avoid interfering with the } \\
\text { habitat of local flora and wildlife }\end{array}$ \\
\hline & lf_conserve & $\begin{array}{l}\text { The role of sustainably managed tourist } \\
\text { areas goes beyond their economic } \\
\text { function }\end{array}$ \\
\hline & lf_develop & $\begin{array}{l}\text { Sustainable tourism can enhance } \\
\text { visitors' personal development }\end{array}$ \\
\hline & If_payment & $\begin{array}{l}\text { Visiting sustainably managed tourist } \\
\text { areas should be subject to a higher } \\
\text { relative payment }\end{array}$ \\
\hline & lf_restrict & $\begin{array}{l}\text { Tourism in sustainably managed tourist } \\
\text { areas should restrict visits to preserve } \\
\text { important cultural values and norms }\end{array}$ \\
\hline & If_fundconserv & $\begin{array}{l}\text { Part of the income from tourism should } \\
\text { fund the promotion of environmental } \\
\text { and cultural conservation }\end{array}$ \\
\hline \multirow[t]{6}{*}{$\begin{array}{l}\text { Pro-environmental } \\
\text { private behaviour }\end{array}$} & If_energy & $\begin{array}{l}\text { I own energy-efficient household } \\
\text { devices }\end{array}$ \\
\hline & lf_nearby & $\begin{array}{l}\text { In nearby areas (around } 20 \text { miles) I use } \\
\text { public transportation or ride a bicycle }\end{array}$ \\
\hline & lf_transport & $\begin{array}{l}\text { I ride a bicycle or take public transport } \\
\text { to work or school/university }\end{array}$ \\
\hline & If_envorg & $\begin{array}{l}\text { I am an active member of an } \\
\text { environmental organisation }\end{array}$ \\
\hline & lf_read & $\begin{array}{l}\text { I read articles, magazines, or books } \\
\text { about environmental issues }\end{array}$ \\
\hline & lf_donate & I donate to environmental organisations \\
\hline \multirow[t]{5}{*}{ Environmental beliefs } & lf_interfere & $\begin{array}{l}\text { When humans interfere with nature, it } \\
\text { often produces disastrous consequences }\end{array}$ \\
\hline & If_abuse & $\begin{array}{l}\text { Humans are severely abusing the } \\
\text { environment }\end{array}$ \\
\hline & If_equality & $\begin{array}{l}\text { Plants and animals have as much right } \\
\text { as humans to exist }\end{array}$ \\
\hline & lf_balance & $\begin{array}{l}\text { The balance of nature is very delicate } \\
\text { and easily upset }\end{array}$ \\
\hline & lf_intrinsic & $\begin{array}{l}\text { Nature has great value which makes its } \\
\text { conservation important for current and } \\
\text { future generations }\end{array}$ \\
\hline
\end{tabular}

for each of them they are asked to choose between two or more mutually exclusive alternatives. Alternatives are described by a set of attributes that vary between different levels to define potential tourism options 
(Johnston et al., 2017; Hensher et al., 2005; Hoyos, 2010). The attributes and levels used in this study are summarised in Table 3 and were selected following a literature review and the feedback from a consultation process with stakeholders and practitioners in Fiji and in the UK. Attributes are framed to explicitly capture the different dimensions of sustainable tourism development. The environmental dimension is described through the protection of natural habitats. The socio-cultural dimension is proxied by the preservation of local indigenous communities and heritage (so called $\mathrm{Vanua}^{2}$ ) through tourist access limitations. Finally, tourism industry sustainability and economic performance is expressed by the eco-friendly management of accommodation facilities and the project investment timeframe. The inclusion of a payment vehicle allows a measurement of WTP for changes in attributes' levels that can be used to inform policy makers (Champ et al., 2017). ${ }^{3}$ One-off donation is considered in this study to be the most appropriate payment mechanism given the remoteness of the study area, the credibility of the choice situations and to mitigate protest behaviour. ${ }^{4}$ The levels used for the one-off donation are framed on typical amounts donated in the UK

Table 3

Description of attributes and levels used in the CE.

\begin{tabular}{|c|c|c|}
\hline Attributes & Levels & Status quo \\
\hline Habitat & $\begin{array}{l}\text { 1) Mangroves } \\
\text { 2) Sandy beaches } \\
\text { 3) Coral reef } \\
\text { 4) Seagrasses }\end{array}$ & No specific habitat \\
\hline $\begin{array}{l}\text { Eco-friendly tourist } \\
\text { accommodation } \\
\text { management }\end{array}$ & $\begin{array}{l}\text { 1) No action } \\
\text { 2) Waste management } \\
\text { 3) Waste management and } \\
\text { Energy and water savings }\end{array}$ & No action \\
\hline $\begin{array}{l}\text { Community management } \\
\text { for tourism (Vanua) }\end{array}$ & $\begin{array}{l}\text { 1) No visits allowed } \\
\text { 2) Visits possible but } \\
\text { moderate access } \\
\text { 3) Free to visit }\end{array}$ & $\begin{array}{l}\text { Visits possible but } \\
\text { moderate access }\end{array}$ \\
\hline $\begin{array}{l}\text { Time for project } \\
\text { implementation }\end{array}$ & $\begin{array}{l}\text { 1) Immediately } \\
\text { 2) } 5 \text { years } \\
\text { 3) } 10 \text { years } \\
\text { 4) } 25 \text { years }\end{array}$ & No implementation \\
\hline Payment vehicle-Donation & $\begin{array}{l}\text { 1) } £ 10 \\
\text { 2) } £ 20 \\
\text { 3) } £ 40 \\
\text { 4) } £ 60 \\
\text { 5) } £ 80 \\
\text { 6) } £ 100\end{array}$ & No donation \\
\hline
\end{tabular}

\footnotetext{
${ }^{2}$ Vanua is the Fijian concept of sense of place describing the connection and harmonious co-existence between people and the environment (Kerstetter \& Bricker, 2009).

${ }^{3}$ Selecting the most suitable payment vehicle is crucial for consequentiality and incentive-compatibility in CEs (Carson et al., 2014; Carson \& Groves, 2007).

${ }^{4}$ Although donations are regarded to have lower incentive compatibility than other payment vehicles (Carson et al., 2014; Carson \& Groves, 2007), voluntary donations have been widely employed in CEs literature, particularly in measuring WTP for remote ecosystem goods and services (e.g. Morse-Jones et al., 2012; Rolfe et al., 2000). Further, the UK is among the countries where citizens donate to charities the most (Charities Aid Foundation, 2019), making voluntary donation a relevant and familiar payment vehicle.
}

(Charities Aid Foundation, 2017) and were pilot tested.

The five attributes were combined in 24 choice cards using an efficient experimental design. ${ }^{5}$ Fig. 1 shows an example of the choice card. Each respondent was presented with six choice cards, each including two alternatives for ecotourism projects and a status quo. The status quo is added so that the trade-off is made with respect to a baseline situation, adding consistency to the theoretical framework (Bateman et al., 2002; Carson \& Groves, 2007).

\begin{tabular}{|c|c|c|c|}
\hline $\begin{array}{l}\text { INFORMATION about the } \\
\text { more sustainable tourism } \\
\text { project in Fiji }\end{array}$ & $\begin{array}{l}\text { Current } \\
\text { situation }\end{array}$ & Project A & Project B \\
\hline Natural habitat & N/A & Mangroves & Seagrasses \\
\hline $\begin{array}{l}\text { Eco-friendly tourist } \\
\text { accommodation } \\
\text { management }\end{array}$ & No action & $\begin{array}{l}\text { Waste management } \\
\& \text { Energy and water } \\
\text { savings }\end{array}$ & No action \\
\hline $\begin{array}{l}\text { Community management } \\
\text { for tourism (Vanua) }\end{array}$ & $\begin{array}{l}\text { Visits possible } \\
\text { but moderate } \\
\text { access }\end{array}$ & No visits allowed & $\begin{array}{l}\text { Free to } \\
\text { visit }\end{array}$ \\
\hline $\begin{array}{l}\text { Time for project } \\
\text { implementation }\end{array}$ & N/A & Immediately & 25 years \\
\hline Donation & No donation & $£ 60$ & $£ 20$ \\
\hline
\end{tabular}

Before the CE, respondents were briefed with a comprehensive characterisation of the main ecosystems in Fiji followed by the description of the policy context, namely the potential benefits of ecotourism development in SIDS. ${ }^{6}$ The choice cards were set in context through an attributes' explanation, cheap talk strategies, and opt-out and individual budget reminders.

\subsection{Survey data collection and sample characteristics}

Data were collected using an online survey administered through the web panel of a professional survey company ${ }^{7}$ and targeting UK residents. Online surveys are now widely employed in valuation studies and have been found to yield reliable WTP measures (Lindhjem \& Navrud, 2011; Olsen, 2009; Windle \& Rolfe, 2011). After extensive pre-testing on a sample of UK residents, the full survey was administered in December 2017. National representativeness quotas were defined based on gender, age, and geographical region according to the UK population data from Office for National Statistics (2017). In total 1171 individuals started the survey; of these, around $72 \%$ successfully completed it. Therefore, the final sample is composed of 843 UK citizens. Respondents who already visited and never visited a SIDS differ both in terms of socio-demographic and holiday habit characteristics. Respondents who have already visited a SIDS destination at least once are slightly younger, better educated, more likely to be employed, and generally

\footnotetext{
5 The experimental design was developed in two steps. In the first step, a Defficient design was generated (D-error $=0.0318$ ). The design was used to carry out a pilot survey. In the second step, estimated coefficients from a multinomial logit on pilot data were used as priors to generate a Bayesian D-efficient design (Bliemer \& Collins, 2016; Ferrini \& Scarpa, 2007) with 24 choice situations randomised into four blocks (D-error $=0.0315$ ). The design priors were re-defined after 325 observations of the main survey, leading to a sequential improvement of the Bayesian D-efficient design (D-error $=0.0287$ ). For a review of design efficiency measures see Scarpa and Rose (2008). Experimental designs were developed using Ngene 1.1.2 (ChoiceMetrics, 2014).

6 This detailed description was considered necessary due to the remoteness and complexity of the proposed ecotourism projects and to mitigate information and hypothetical biases (Bateman et al., 2002; Carson \& Groves, 2007; Fifer et al., 2014; Hensher, 2010).

7 The survey was developed on SurveyMonkey platform. The sample of UK residents was provided by Survey Sampling International-Dynata. Respondents were directly recruited by the survey company from its permissioned first-party panel of opted-in consumers. A daily target of respondents recruited and surveys completed was established in order to increase the control on data collection and its overall consistency.
} 


\begin{tabular}{|l|c|c|c|}
\hline $\begin{array}{l}\text { INFORMATION about the more } \\
\text { sustainable tourism project in Fiji }\end{array}$ & Current situation & Project A & Project B \\
\hline Natural habitat & N/A & Mangroves & Seagrasses \\
\hline $\begin{array}{l}\text { Eco-friendly tourist } \\
\text { accommodation management }\end{array}$ & $\begin{array}{c}\text { Waste management } \\
\text { \& Energy and water } \\
\text { savings }\end{array}$ & No action \\
\hline $\begin{array}{l}\text { Community management for tourism } \\
\text { (Vanua) }\end{array}$ & $\begin{array}{c}\text { Visits possible but } \\
\text { moderate access }\end{array}$ & No visits allowed & Free to visit \\
\hline Time for project implementation & No donation & Immediately & 25 years \\
\hline Donation & \multicolumn{2}{|c|}{ f20 } \\
\hline
\end{tabular}

Fig. 1. Example of a choice card.

wealthier than respondents who have never travelled to a SIDS. As for holiday habits, in line with expectations, respondents who have already visited a SIDS travel more frequently and to more diverse destinations. The socio-demographic and the holidays-related characteristics of the sample are detailed in Appendix I.

\section{Results}

\subsection{Latent factor analysis results}

Our assumption is that individual latent attitudes, behaviours, and beliefs can help to segment prospective tourist types and better explain unobserved individual heterogeneity in the analysis of choice experiment data. Therefore, in this paper, rather than reporting latent factor analysis and choice experiment results independently, we aim to provide a joint analysis where latent factors contribute to explain the WTP heterogeneity. Before including the latent factors into the choice model, attitudinal and behavioural questions are independently analysed to assess their validity and reliability (see Appendix II for details). ${ }^{8}$ Table 4 reports the summary statistics of the indicators used in our analysis. If, on average, an indicator scores high, this implies that respondents care more about the corresponding latent trait. Table 4 shows that mean indicator ratings are systematically higher for Environmental beliefs and Eco-tourism attitudes than for Pro-environmental private behaviour. At the same time, the factor Pro-environmental private behaviour shows higher variability across respondents, as the standard deviations of the corresponding indicators, lf_envorg, lf_read and lfdonate, are higher than the others.

Results from the exploratory factor analysis are summarised in Table 5. Indicator loadings seem to support the three-factors structure. In fact, the indicators selected to describe the factor Pro-environmental private behaviour, that is $l_{-}$envorg, $l f_{-}$read, and lf_donate, strongly load on the same, stand-alone factor (Factor 2 in Table 5). From the first column of Table 5 (labelled Factor 1), indicators lfinterfere, lfabuse, lf_equality, lf_balance, and lfintrinsic have factor loadings higher than 0.65 on the same factor, and can then be consistently used to describe the Environmental beliefs. Finally, lf_avoid, lf_conserve, lf_develop, lf_payment, lf_restrict, and Iffundconserve might characterise the same Eco-tourism attitudes factor (Factor 3 in Table 5), even if some factor loadings are less definite.

The reliability of the latent factors structure in Table 5 is subsequently tested calculating Cronbach's alpha (Cronbach, 1951) and

\footnotetext{
8 After a preliminary check of the correlations and the exploratory factor analysis, we detected some critical issues related to the indicators lf_energy, lf nearby, and lf_transp. Therefore, to reach the most reliable and coherent solution, those indicators were discarded from the analysis.
}

Table 4

Descriptive statistics of the latent factors' indicators.

\begin{tabular}{cllll}
\hline Latent factor & Indicator & Observations & $\begin{array}{l}\text { Mean } \\
\text { ratings }\end{array}$ & $\begin{array}{l}\text { Standard } \\
\text { deviation }\end{array}$ \\
\hline $\begin{array}{c}\text { Pro-environmental } \\
\text { private behaviour }\end{array}$ & lf_envorg & 828 & 2.23 & 1.32 \\
& lf_read & 824 & 3.14 & 1.31 \\
Environmental & lf_donate & 827 & 2.75 & 1.33 \\
beliefs & lf_interfere & 832 & 4.17 & 0.85 \\
& lf_abuse & 833 & 4.32 & 0.85 \\
& lf_equality & 829 & 4.37 & 0.86 \\
Eco-tourism & lf_balance & 820 & 4.35 & 0.81 \\
attitudes & lf_intrinsic & 825 & 4.43 & 0.81 \\
& lf_avoid & 827 & 4.23 & 0.90 \\
& lf_conserve & 792 & 3.96 & 0.92 \\
& lf_develop & 800 & 4.07 & 0.84 \\
& lf_payment & 800 & 3.65 & 0.99 \\
& lf_restrict & 811 & 3.99 & 0.89 \\
& lf_fundconserv & 819 & 4.27 & 0.85 \\
\hline
\end{tabular}

Table 5

Results from the exploratory factor analysis.

\begin{tabular}{llll}
\hline Variable & Factor 1 & Factor 2 & Factor 3 \\
\hline lf_envorg & & $\mathbf{0 . 8 3 8}$ & \\
lf_read & 0.219 & $\mathbf{0 . 7 5 5}$ & \\
lf_donate & & $\mathbf{0 . 8 0 6}$ & \\
lf_interfere & $\mathbf{0 . 6 9 8}$ & & 0.215 \\
lf_abuse & $\mathbf{0 . 8 2 4}$ & & \\
f_equality & $\mathbf{0 . 7 8 0}$ & & \\
lf_balance & $\mathbf{0 . 8 4 0}$ & & \\
lf_intrinsic & $\mathbf{0 . 8 5 8}$ & & 0.258 \\
lf_avoid & $\mathbf{0 . 6 3 2}$ & & 0.479 \\
lf_conserve & 0.405 & 0.207 & $\mathbf{0 . 5 7 1}$ \\
lf_develop & 0.497 & 0.252 & $\mathbf{0 . 5 2 1}$ \\
lf_payment & 0.237 & 0.364 & $\mathbf{0 . 5 4 2}$ \\
f_restrict & 0.488 & & $\mathbf{0 . 5 4 5}$ \\
lf_fundconserv & $\mathbf{0 . 6 5 2}$ & & 0.517 \\
Eigenvalue & 6.445 & 2.013 & 0.512 \\
Proportion of explained variance & 0.555 & 0.255 & 0.221 \\
\hline
\end{tabular}

Loevinger's H (Hemker et al., 1995; Loevinger, 1948) coefficients (Table 6). As all coefficients are well above the thresholds, we can conclude that our latent factors pass the test of reliability ${ }^{9}$ and improve the understanding of the choice experiment preferences.

\footnotetext{
${ }^{9}$ All latent factor scales present a very good internal consistency, with alpha coefficients always higher than 0.80 , and global scalability, with Loevinger's coefficients always higher than 0.30 . Further, the three-factors solution was confirmed using a confirmatory factor analysis. The model fits well, with a standardised root mean squared residual lower than 0.08 (Hu \& Bentler, 1999).
} 
Table 6

Reliability coefficients.

\begin{tabular}{lll}
\hline Latent factor & $\begin{array}{l}\text { Cronbach's alpha } \\
\text { coefficient }\end{array}$ & $\begin{array}{l}\text { Loevinger's H } \\
\text { coefficient }\end{array}$ \\
\hline Environmental beliefs & 0.874 & 0.628 \\
Attitudes toward eco-tourism & 0.841 & 0.520 \\
$\begin{array}{l}\text { Pro-environmental private } \\
\text { behaviour }\end{array}$ & 0.812 & 0.653 \\
\hline
\end{tabular}

\subsection{Choice experiment results}

The responses to the CE questions are first analysed with the multinomial logit model (MNL) which assumes that observable and unobservable preferences are homogenous. The unobservable preferences due to heterogeneity in the error term can be captured using a scaled MNL model. However, in order to relax the homogeneity in observable preferences, we employ the latent class logit model (LCL) ${ }^{10}$. Details on the models used are in Appendix II. Table 7 reports the models' results. The MNL is reported for the pooled sample (Model MNL), the sample of UK residents who have already visited SIDS (Model MNL-V) and the sample of those who have never visited SIDS (Model MNL-NV). ${ }^{11}$ The LCL model accommodates preference heterogeneity, clustering respondents according to their common latent traits. ${ }^{12}$ The clustering of respondents follows a logistic distribution, as described in Appendix II, and which might be influenced by observable socio-economic characteristics or latent factors. In this case we include in the LCL model the combined effect of past experience, pro-environmental private behaviour, environmental beliefs, and eco-tourism attitudes.

The inclusion of latent factors into the LCL provides a three-class model that suggests that preferences can be clustered in three homogenous groups (last three columns of Table 7). People in each group share similar WTPs. Groups differ with respect to respondents' unobservable traits. Group $C$ is the reference category and we can observe that, compared to this group, Groups A and B have a higher probability to have visited SIDS, have stronger pro-environmental private behaviours and, for group B, express stronger eco-tourism attitudes.

Considering the preference heterogeneity in tourism factors, we observe that the environmental-friendly visitors (Class A) generally prefer that projects for the sustainable management of tourism development are implemented and completed sooner within the timeline proposed in the CE. They have positive and significant preferences for the protection of all habitat types but are not willing to donate if the sustainably managed areas are subject to any form of access restriction. They are also indifferent between tourism accommodation management practices.

The eco-tourists (Class B) also prefer that projects for the sustainable management of tourism development take place, but with a stronger intensity than those in Class A, and realised sooner within the timeline proposed in the CE. They are indifferent about the amount to donate to sustainable tourism projects and would moderately restrict access to the sustainably managed areas, possibly considering it as a suitable way of protecting cultural identity. They strongly prefer the highest standard for the management of tourist accommodations and have clear preferences for coral reefs preservation.

\footnotetext{
10 The scaled MNL was estimated using the Stata (StataCorp, 2017) package clogithet (Hole, 2006) and the LCL model was estimated using the Stata package lclogit (Pacifico \& Yoo, 2013).

11 The feasibility of using a split sample was tested by estimating an MNL model including interactions between the attributes and a dummy indicator for the visited/not visited status. Most interaction terms' coefficients were statistically significant, so that using a split sample has been considered robust.

12 The choice of the optimal number of latent classes for the LCL relies on the examination of AIC and CAIC. Several LCL models with different number of classes are estimated and the one with the smallest AIC and CAIC is selected.
}

The indifferent non-visitors (Class $\mathrm{C}$, reference class) are generally indifferent to sustainable tourism projects taking place, report a strong and significant lack of willingness to donate to fund sustainable tourism practices, show no preference between habitats to be protected and types of accommodation management. They also show very strong dissatisfaction related to the lack of access to the sustainably managed areas. Compared to the other classes, respondents in Class $\mathrm{C}$ are more likely to have not previously visited a tropical destination. They also display lower private eco-friendly behaviour and attitudes toward ecotourism. Concerning socio-demographic characteristics, compared to the other classes, respondents in this class are generally older, with a lower level of education and a slightly lower personal income. Also, they are slightly more likely to be retired or unemployed and live in a household with no children.

\subsection{Willingness to pay for sustainable tourism development}

Table 8 reports the marginal WTP values that represents the amount that individuals are willing to pay as a one-off donation in relation to a specific attribute. A positive marginal WTP means that, on average, respondents receive utility (i.e. satisfaction) from a specific attribute and are willing to donate more. On the other hand, a negative marginal WTP means that, on average, respondents suffer a disutility (i.e. dissatisfaction) from a specific attribute and are not willing to donate.

Considering the MNL model (which just explains the homogenous preferences for tourism factors assuming no differences across respondents) results show that respondents are most willing to increase their donations if tourist accommodations employ the highest standard of sustainability, that is both waste management and energy and water saving practices. They are willing to donate £85.31 and £57.59, respectively whether they have already visited or not visited a SIDS destination. Respondent donation decreases if access to the new sustainably managed areas is forbidden, particularly for those who have already visited a SIDS destination. They are willing to donate $£ 61.92$ less. Respondents with past experience of SIDS are willing to donate considerably more, $£ 61.85$ and $£ 47.34$, to protect corals and mangroves respectively. Also, respondents without the same experience are willing to donate more to protect natural ecosystems, but only if they are coral reefs ( $£ 19.80$ more); their donation would instead decrease by $£ 13.32$ if mangroves are the targeted protection habitat. All respondents present a decreasing willingness to donate if projects are to be implemented in future years.

Once the LCL model is implemented we can disentangle respondents' WTP considering their latent beliefs, attitudes and behaviours. With this model, WTPs are available for the three groups of respondents. The environmental-friendly visitors (Class A) are generally willing to donate more for the protection of all habitats, namely $£ 13.29$ for beaches, $£ 18.49$ for corals, and $£ 8.66$ for mangroves. They would donate less if access is forbidden or somewhat restricted, respectively $£ 30.57$ and $£ 11.53$ less. Also, their donation would be decreased by $£ 0.69$ for each extra year more it takes to project completion. The eco-tourists (Class B) have an insignificant donation coefficient, but significant preferences for some of the attributes (see Table 7). This means that they are indifferent to the donation amount needed to see the completion as soon as possible of projects comprising protection of corals, high environmental standards in accommodation management, and moderate access to the sustainably managed areas. Finally, indifferent non-visitors (Class C) are generally not willing to donate for any sustainable tourism project.

\section{Discussion}

Table 7 presents the results for the pooled and the split (visitors vs non-visitors) samples and their comparison provides interesting insights. Respondents generally hold strong preferences for preserving the iconic coral reefs in Fiji, and are considerably stronger for respondents who visited a SIDS destination in the past. The effect of preserving 
Table 7

Results from the multinomial logit model and latent class logit model.

\begin{tabular}{|c|c|c|c|c|c|c|}
\hline & MNL & MNL-V & MNL-NV & $\begin{array}{l}\text { LCL } \\
\text { Class A }\end{array}$ & $\begin{array}{l}\text { LCL } \\
\text { Class B }\end{array}$ & $\begin{array}{l}\text { LCL } \\
\text { Class C }\end{array}$ \\
\hline Average class share & & & & $35.2 \%$ & $50.3 \%$ & $14.5 \%$ \\
\hline & \multicolumn{6}{|c|}{ Variables used in class allocation probabilities } \\
\hline Visited SIDS & & & & $0.543^{* *}(0.276)$ & $0.562 * *(0.264)$ & - \\
\hline Pro-environmental private behaviour & & & & $0.672^{* *}(0.273)$ & $0.857 * *(0.248)$ & - \\
\hline Environmental beliefs & & & & $0.010(0.353)$ & $0.420(0.324)$ & - \\
\hline \multirow[t]{2}{*}{ Eco-tourism attitudes } & & & & $0.458(0.382)$ & $0.999 * *(0.344)$ & - \\
\hline & \multicolumn{6}{|l|}{ Model coefficients } \\
\hline ASC - Status quo & $-0.415^{* *}(0.121)$ & $-0.425^{* *}(0.184)$ & $-0.525 * *(0.155)$ & $-1.290 * *(0.282)$ & $-3.129 * *(0.400)$ & $1.976(1.318)$ \\
\hline Habitat - Sandy beach & $-0.002(0.033)$ & $0.028(0.059)$ & $-0.001(0.052)$ & $0.321 * *(0.117)$ & $-0.114(0.091)$ & $0.724(0.568)$ \\
\hline Habitat - Coral reef & $0.135^{* *}(0.050)$ & $0.166^{* *}(0.083)$ & $0.134 * *(0.064)$ & $0.447 * *(0.150)$ & $0.185^{*}(0.110)$ & $0.158(0.836)$ \\
\hline Habitat - Mangroves & $0.008(0.033)$ & $0.127 * *(0.063)$ & $-0.090 *(0.056)$ & $0.209 *(0.124)$ & $-0.111(0.093)$ & $0.508(0.586)$ \\
\hline Waste management & $0.171^{* *}(0.060)$ & $0.081(0.084)$ & $0.290 * *(0.088)$ & $0.185(0.148)$ & $-0.412(0.369)$ & $0.791(0.641)$ \\
\hline Waste management + energy and water savings & $0.284 * *(0.071)$ & $0.230 * *(0.086)$ & $0.391 * *(0.094)$ & $0.036(0.155)$ & $0.709 * *(0.117)$ & $0.294(0.898)$ \\
\hline Vanua - No visit allowed & $-0.174 * *(0.053)$ & $-0.167 * *(0.071)$ & $-0.204 * *(0.073)$ & $-0.739 * *(0.135)$ & $-0.121(0.097)$ & $-1.580 * *(0.684)$ \\
\hline Vanua - Moderate access & $-0.001(0.028)$ & $-0.041(0.048)$ & $0.047(0.045)$ & $-0.279 * *(0.103)$ & $0.165^{* *}(0.082)$ & $-0.328(0.451)$ \\
\hline Time or project completion & $-0.007 * *(0.003)$ & $-0.003(0.004)$ & $-0.012 * *(0.005)$ & $-0.017 * *(0.008)$ & $-0.016 * *(0.007)$ & $-0.048(0.043)$ \\
\hline One-off donation & $-0.005^{* *}(0.001)$ & $-0.003 *(0.002)$ & $-0.007^{* *}(0.002)$ & $-0.024 * *(0.003)$ & $0.001(0.002)$ & $-0.041^{* *}(0.013)$ \\
\hline Scale $-18-34$ years old & $-0.389^{* *}(0.127)$ & $0.161(0.342)$ & $-0.511 * *(0.170)$ & & & \\
\hline Scale - 35-64 years old & $-0.347 * *(0.104)$ & $-0.031(0.267)$ & $-0.328 * *(0.130)$ & & & \\
\hline Scale - upper secondary & $0.795 * *(0.245)$ & $0.201(0.501)$ & $0.634 * *(0.234)$ & & & \\
\hline Scale - university/professional qual. & $0.999 * *(0.247)$ & $0.694 *(0.406)$ & $0.782 * *(0.234)$ & & & \\
\hline Scale - post-graduate & $0.950 * *(0.280)$ & $0.576(0.463)$ & $0.823 * *(0.288)$ & & & \\
\hline $\mathrm{N}$ & 842 & 304 & 538 & 843 & & \\
\hline Log Likelihood & -5254.29 & -1878.03 & -3345.99 & -4297.07 & & \\
\hline
\end{tabular}

Notes: ** statistical significance at $5 \%$ level, * statistical significance at $10 \%$ level; standard errors in parenthesis.

Table 8

Marginal willingness to pay for sustainable development attributes (in $£$ value).

\begin{tabular}{|c|c|c|c|c|c|c|}
\hline & MNL & MNL-V & MNL-NV & $\begin{array}{l}\text { LCL } \\
\text { Class A } \\
\text { Environmental friendly visitors }\end{array}$ & $\begin{array}{l}\text { LCL } \\
\text { Class B } \\
\text { Eco-tourists }\end{array}$ & $\begin{array}{l}\text { LCL } \\
\text { Class C } \\
\text { Indifferent non-visitors }\end{array}$ \\
\hline Habitat - Sandy beach & -0.33 & 10.39 & -0.16 & $13.29^{*}$ & -197.70 & 3.87 \\
\hline Habitat - Coral reef & $29.97^{*}$ & $61.85^{*}$ & $19.80 *$ & $18.49^{*}$ & 322.33 & 17.78 \\
\hline Habitat - Mangroves & 1.76 & $47.34^{*}$ & $-13.32^{*}$ & $8.66^{*}$ & -193.27 & 12.47 \\
\hline Waste management & $37.84^{*}$ & 29.94 & $42.75^{*}$ & 7.65 & -715.29 & 19.42 \\
\hline Waste management + energy and water savings & $62.92 *$ & $85.31^{*}$ & $57.59 *$ & 1.50 & 1232.51 & 7.21 \\
\hline Vanua - No visit allowed & $-38.51 *$ & $-61.92^{*}$ & $-30.04 *$ & $-30.57 *$ & -210.97 & $-38.78^{*}$ \\
\hline Vanua - Moderate access & -0.17 & -15.22 & 6.87 & $-11.53^{*}$ & 287.51 & -8.04 \\
\hline Time for project completion & $-1.55^{*}$ & $-1.27^{*}$ & $-1.73^{*}$ & $-0.69 *$ & -27.60 & -1.18 \\
\hline
\end{tabular}

Notes: * significant MWTP: attribute model coefficient and donation model coefficient are both statistically significant.

mangrove forests significantly and positively affects the preferences of those who visited a SIDS, but negatively affects preferences for those who have not visited. This result suggests that past experience of SIDS visitation, through increased knowledge, improves peoples' understanding of services provided by the different ecosystems and awareness of the need for their preservation. As far as the management of Vanua preservation is concerned, which represents the cultural factor of tourism, respondents generally favour the opportunity to experience the indigenous culture and therefore wish to access the sustainably managed tourist areas. Indeed, the complete closure of Vanua sites causes a substantial decrease in respondent utility. This result is particularly relevant because it highlights how prospective tourists not only hold non-use values, but also use values (e.g. quasi-option values) for distant cultural ecosystem services. Preferences for the eco-friendly management of tourist accommodations show some degree of divergence. Both groups of visitors have significant positive preferences for eco-friendly management, but those who already visited a SIDS only favour the highest standard (i.e. waste management plus water and energy savings). Respondents, who had already visited SIDS destinations, were not affected by a significant project time delay compared to those who never visited. This suggests that the completion of a project is more relevant than the time spent to complete it. Finally, respondents who have already visited SIDS destinations are on average more likely to donate to sustainable tourism projects.

The LCL analysis helps to understand how the three clusters differ in their attitude towards the tourism factors. Respondents in Classes A (the environmental-friendly visitors) and B (the eco-tourists) hold both direct and indirect use value for the natural resources, compared to the reference Class $\mathrm{C}$ (the indifferent non-visitors). Also, respondents in Classes A and B are more likely to have visited a SIDS. In both Classes A and $\mathrm{B}$, respondents are generally younger and with a higher education than those in Class C. Moreover, there are more respondents in employment and with a high personal income. The socio-demographic characteristics in Classes A and B are similar, with the main difference being the presence of more numerous families in Class B.

Our results indicating a positive WTP to protect remote and endangered ecosystems are in line with previous literature (see Table 9).

Our results confirm that preserving the iconic coral reefs is worth more than preserving unfamiliar remote species, echoing the finding in Morse-Jones et al. (2012). Our findings also suggest that prospective tourists not only hold non-use values (Rolfe et al., 2000) but also quasi-option values. The latter is reflected in the decrease in donations that would follow access restrictions to the sustainably managed tourist areas. Results also show that prospective tourists hold positive preferences and are on average willing to pay for tourist accommodations where environmental-friendly practices are implemented, in line with 
Table 9

WTP studies for remote ecosystems and species.

\begin{tabular}{lllc}
\hline Study & $\begin{array}{l}\text { Ecosystem/ } \\
\text { Species }\end{array}$ & Sample & WTP \\
\hline Svedsäter (2000) & $\begin{array}{l}\text { South America } \\
\text { rainforest } \\
\text { Brazilian Amazon }\end{array}$ & $\begin{array}{l}\text { UK students and } \\
\text { Swedish residents } \\
\text { UK and Italian } \\
\text { residents }\end{array}$ & $£ 37.0$ \\
$\begin{array}{l}\text { Swanton et al. (2003) } \\
\text { Kontoleon (2004) }\end{array}$ & $\begin{array}{l}\text { Rhino } \\
\text { Wildifian Black }\end{array}$ & UK residents & $£ 15.2$ \\
$\begin{array}{c}\text { Morse-Jones et al. } \\
\text { (2012) }\end{array}$ & Tanzania & UK residents & $£ 9.7-$ \\
\end{tabular}

some previous literature results (e.g. Hultman et al., 2015; Huybers \& Bennett, 2000; do Valle et al., 2012).

Also, as expected, respondents who have already visited a SIDS are more willing to donate to schemes for the protection of natural habitats (Choi \& Fielding, 2013; Kramer \& Mercer, 1997). They also favour the most environmental-friendly and effective practices related to tourist accommodation. In addition, respondents with higher pro-environmental private behaviours and eco-tourism attitudes are willing to donate more for the protection of remote ecosystem services and, in general, for the development of sustainable tourism programmes in remote destinations.

\section{Conclusions}

Our research aimed to improve the understanding of prospective visitors' preferences and trade-offs for the environmental, social, and economic aspects of sustainable tourism development options in SIDS. The paper provides a mixed methodology combining latent factor analysis and choice experiment models. The joint use of the two methods has the potential to broaden the investigation of tourists' preferences for sustainability by allowing a more thorough exploration of diverse determinants, and can be flexibly adapted to different topics in the wider context of sustainable tourism development. The empirical results of our study contribute to a better understanding of Western residents' preferences about sustainable development and sustainable tourism projects in remote destinations. They also provide an opportunity to target specific types of tourists (environmental-friendly Class A visitors and ecotourists Class B) and match them to specific destinations.

Although our analysis is based on findings for Fiji our recommendations can be generalised, offering useful insights for sustainable tourism development in other SIDS. At the same time, the joint modelling of economic, environmental and socio-cultural factors related to sustainable tourism projects, sheds light on how respondents perceive and value the trade-offs. Overall, our findings may help to better appraise sustainability projects involving resource flows between developed and developing countries and to help enable more resilient sustainable tourism plans, interventions, and cooperation. Our project results also suggest the need to raise awareness about the importance of the natural capital and local cultures in tropical countries with potential tourists, so to incentivise sustainable tourism. From a financial perspective, policy makers in SIDS could use our results to consider developing new payment for ecosystem services schemes tailored for sustainable tourism projects. For example, payment schemes that promote more sustainable practices (e.g. improved waste and water treatment) through the creation of a local labelling system for tourist resorts; or to create new types of sustainable entrance tickets (e.g. limited in number and per season) to the communities, or to the marine protected areas.

\section{Declaration of competing interest}

None.

\section{CRediT authorship contribution statement}

Gaetano Grilli: Conceptualization, Methodology, Formal analysis, Data curation, Writing - original draft, Writing - review \& editing. Emmanouil Tyllianakis: Conceptualization, Writing - review \& editing. Tiziana Luisetti: Conceptualization, Writing - review \& editing. Silvia Ferrini: Writing - review \& editing. R. Kerry Turner: Writing review \& editing.

Appendix I. Descriptive statistics of the sample

\begin{tabular}{|c|c|c|c|c|}
\hline Variable & Categories & $\begin{array}{l}\text { Total sample }(\%) \\
(\mathrm{N}=843)\end{array}$ & $\begin{array}{l}\text { Visited SIDS destination (\%) } \\
(\mathrm{N}=305)\end{array}$ & $\begin{array}{l}\text { Never visited SIDS destination (\%) } \\
(\mathrm{N}=538)\end{array}$ \\
\hline \multirow[t]{2}{*}{ Gender } & Female & 51.0 & 44.6 & 54.6 \\
\hline & Male & 49.0 & 55.4 & 45.4 \\
\hline \multirow[t]{6}{*}{ Age } & 18-24 years old & 12.0 & 11.5 & 12.3 \\
\hline & $25-34$ years old & 16.6 & 23.6 & 12.6 \\
\hline & 35-44 years old & 17.8 & 16.4 & 18.6 \\
\hline & 45-54 years old & 18.0 & 16.4 & 19.0 \\
\hline & 55-64 years old & 15.1 & 12.1 & 16.7 \\
\hline & 65 years old and over & 20.5 & 20.0 & 20.8 \\
\hline \multirow[t]{5}{*}{ Region } & Scotland and N. Ireland & 11.5 & 7.8 & 13.6 \\
\hline & Northern England & 22.9 & 18.7 & 25.3 \\
\hline & Central England & 29.9 & 27.9 & 31.0 \\
\hline & Southern England & 22.9 & 27.2 & 20.4 \\
\hline & London area & 12.8 & 18.4 & 9.7 \\
\hline \multirow[t]{4}{*}{ Education level attained } & Upper secondary & 49.2 & 40.0 & 54.5 \\
\hline & University qualification & 33.0 & 40.4 & 28.8 \\
\hline & Professional Qualification & 9.6 & 9.8 & 9.5 \\
\hline & $\mathrm{PhD}$ qualification & 8.2 & 9.8 & 7.2 \\
\hline \multirow[t]{4}{*}{ Working condition } & Employed & 54.4 & 67.5 & 47.0 \\
\hline & Unemployed & 5.3 & 4.3 & 6.0 \\
\hline & Retired & 22.5 & 19.3 & 24.4 \\
\hline & Other & 17.7 & 8.9 & 22.7 \\
\hline \multirow[t]{3}{*}{ Household composition } & One person & 19.1 & 16.1 & 20.8 \\
\hline & Single parent & 3.4 & 3.9 & 3.2 \\
\hline & 2 adults, no children & 32.9 & 33.1 & 32.7 \\
\hline
\end{tabular}


(continued)

\begin{tabular}{|c|c|c|c|c|}
\hline Variable & Categories & $\begin{array}{l}\text { Total sample (\%) } \\
(\mathrm{N}=843)\end{array}$ & $\begin{array}{l}\text { Visited SIDS destination (\%) } \\
(\mathrm{N}=305)\end{array}$ & $\begin{array}{l}\text { Never visited SIDS destination (\%) } \\
(\mathrm{N}=538)\end{array}$ \\
\hline & 2 adults, with children & 20.9 & 23.3 & 19.5 \\
\hline & $3+$ adults, no children & 13.3 & 12.1 & 13.9 \\
\hline & $3+$ adults, with children & 10.4 & 11.5 & 9.8 \\
\hline Personal Income & & $£ 15,001$ to $£ 25,000$ & $£ 25,001$ to $£ 35,000$ & $£ 15,001$ to $£ 25,000$ \\
\hline Household income & & $£ 30,001$ to $£ 50,000$ & $£ 30,001$ to $£ 50,000$ & $£ 20,001$ to $£ 30,000$ \\
\hline \multirow[t]{3}{*}{ Frequency of holidays - general } & Less than once per year & 28.9 & 20.7 & 33.6 \\
\hline & Once per year or more & 69.5 & 78.3 & 64.5 \\
\hline & Don't' know & 1.6 & 1.0 & 1.9 \\
\hline \multirow[t]{3}{*}{ Frequency of holidays - last year } & Less than two times & 62.7 & 55.7 & 66.7 \\
\hline & More than three times & 31.1 & 42.6 & 24.6 \\
\hline & Do not know & 6.2 & 1.7 & 8.7 \\
\hline \multirow[t]{4}{*}{ Favourite destination } & United Kingdom & 37.4 & 28.5 & 42.4 \\
\hline & European Union & 37.5 & 36.7 & 37.9 \\
\hline & Outside European Union & 19.0 & 33.1 & 11.0 \\
\hline & Do not know & 6.2 & 1.7 & 8.7 \\
\hline \multirow[t]{2}{*}{ Visited sustainable destination } & No & 77.7 & 56.1 & 90.0 \\
\hline & Yes & 22.3 & 43.9 & 10.0 \\
\hline
\end{tabular}

\section{Appendix II. Econometric models}

The utility obtained by individual $n$ from choosing alternative $i$ is composed of an observable deterministic part $V_{n i}$ and an unobserved random component $\varepsilon_{n i}$

$U_{n i}=V_{n i}+\varepsilon_{n i}=\beta_{i} x_{n i}+\varepsilon_{n i}$

and the resulting multinomial logit model (MNL) probability for individual $n$ of choosing alternative $i$ is (McFadden, 1974) $)^{13}$

$P_{n i}=\frac{e^{\mu_{n} \beta x_{n i}}}{\sum_{j=1}^{J} e^{\mu_{n} \beta x_{n j}}}$

A popular way to account for preference heterogeneity is to use a latent class logit model (LCL). The LCL has been preferred to link taste heterogeneity to individual characteristics such as latent factors (Hensher \& Greene, 2003; Hess \& Daly, 2014; Hess et al., 2009). The LCL is preferred here to a hybrid choice model specification (Ben-Akiva et al., 2002) because the aim is to segment respondents based on the latent factors more than explicitly exploring their impact on taste coefficients. The flexibility of the LCL arises when a class allocation model is used to link class probabilities to characteristics of respondents (Hess et al., 2009)

$\pi_{n k}=\frac{e^{\delta_{k}+g\left(\omega_{k}, z_{n}\right)}}{\sum_{l=1}^{K} e^{\delta_{l}+g\left(\omega_{l}, z_{n}\right)}}$

where $\delta_{k}$ is a class-specific constant, $z_{n}$ is the vector of individual characteristics, $\omega_{k}$ the related parameters. In this analysis, the individual characteristics $z_{n}$ are the latent factors defined in Section 3.1. The derivation of such variables is briefly summarised. For more details, see Kline (2010), Bollen (1989), Nunnally and Bernstein (1994). The 17 indicators presented in the survey questionnaire can be considered as the observed manifestation of underlying latent individual factors. Once indicators are measured, their capacity to describe the intended latent factors needs to be tested. Exploratory factor analysis is used to group indicators describing the same underlying factor, which are subsequently tested for reliability using the Cronbach's alpha (Cronbach, 1951) and the Loevinger's H coefficient (Hemker et al., 1995; Loevinger, 1948). Confirmatory factor analysis is then employed to confirm the statistical significance of the procedure. If significance is confirmed, an individual "score" on each latent factor is calculated. Finally, binary indicators to be used in the LCL class allocation are derived. If the score of individual $n$ on the latent factor $l$ is $s_{n l}$ and the median score in the sample for the factor $l$ is $\operatorname{med}\left(s_{l}\right)$, the indicator variable is

$\operatorname{ind}_{n}\left(l f_{l}\right)=\left\{\begin{array}{lll}1 & \text { if } & s_{n l}>\operatorname{med}\left(s_{l}\right) \\ 0 & \text { if } & s_{n l} \leq \operatorname{med}\left(s_{l}\right)\end{array}\right.$

\section{Impact statement}

This paper contributes to a clearer understanding of tourists' preferences and values for sustainable development and tourism opportunities providing relevant information to policy makers and tourism managers, particularly in small islands destinations. Results can be used to guide and inform policies and plans for sustainable development at the destination, balancing the trade-offs between environmental, social, and economic aspects. The investigation of factors influencing prospective tourists' preferences can support the definition of new market segments and consolidate existing ones. The empirical analysis of the willingness to pay can help to tailor new payment for ecosystem services schemes promoting sustainable practices such as labelling systems and entrance fees. Moreover, results may help to better appraise resources flows between tourists' origin and

\footnotetext{
13 The term $\mu_{n}$ is the scale parameter accounting for the heterogeneity in the variance of the unobserved error term (DeShazo \& Fermo, 2000; Hensher et al., 2005; Hole, 2006; Train, 2009). It is inversely proportional to the error variance, that is equal to $\mu_{n}=\pi / \sqrt{6 \sigma_{n}^{2}}$. This heteroscedastic MNL or scaled MNL, contrary to the typical specification, allows an unequal error variance across respondents functional to individual characteristics $z_{n}$. Here, education and age are the only individual characteristics to have a significant effect on the scale parameter.
} 
destination countries that are needed to meet sustainability targets and to advise sustainable tourism plans, interventions, and cooperation.

\section{References}

Alexandros, A., \& Jaffry, S. (2005). Stated preferences for two Cretan heritage attractions. Annals of Tourism Research, 32(4), 985-1005.

Barrowclough, D. (2007). Foreign investment in tourism and small island developing States. Tourism Economics, 13(4), 615-638.

Bateman, I. J., Carson, R. T., Day, B., Hanemann, W. M., Hanley, N., Hett, T., Lee, M. J., Loomes, G., Mourato, S., Özdemiroglu, E., Pearce, D., Sugden, R., \& Swanson, J. (2002). Economic valuation with stated preference techniques: A manual. Cheltenham: Edward Elgar.

Ben-Akiva, M., McFadden, D., Train, K., Walker, J., Bhat, C., Bierlaire, M., Bolduc, D., Boersch-Supan, A., Brownstone, D., Bunch, D. S., Daly, A., De Palma, A., Gopinath, D., Karlstrom, A., \& Munizaga, M. A. (2002). Hybrid choice models: Progress and challenges. Marketing Letters, 13, 163-175.

Bernard, K., \& Cook, S. (2015). Luxury tourism investment and flood risk: Case study on unsustainable development in Denarau island resort in Fiji. International Journal of Disaster Risk Reduction, 14, 302-311.

Bliemer, M. C. J., \& Collins, A. T. (2016). On determining priors for the generation of efficient stated choice experimental designs. Journal of Choice Modelling, 21, 10-14.

Bojanic, D. C., \& Lo, M. (2016). A comparison of the moderating effect of tourism reliance on the economic development for islands and other countries. Tourism Management, 53, 207-214.

Bollen, K. A. (1989). Structural equations with latent variables. New York: Wiley.

Boxall, P. C., \& Adamowicz, W. L. (2002). Understanding heterogeneous preferences in random utility models: A latent class approach. Environmental and Resource Economics, 23(4), 421-446.

Buckley, R. (2012). Sustainable tourism: Research and reality. Annals of Tourism Research, 39(2), 528-546.

Carson, R. T., \& Groves, T. (2007). Incentive and informational properties of preference questions. Environmental and Resource Economics, 37(1), 181-210.

Carson, R. T., Groves, T., \& List, J. A. (2014). Consequentiality: A theoretical and experimental exploration of a single binary choice. Journal of the Association of Environmental and Resource Economists, 1, 171-207.

Castellanos-Verdugo, M., Vega-Vázquez, M., Oviedo-García, M.Á., \& Orgaz-Agüera, F. (2016). The relevance of psychological factors in the ecotourist experience satisfaction through ecotourist site perceived value. Journal of Cleaner Production, 124, 226-235.

Chaminuka, P., Groeneveld, R. A., Selomane, A. O., \& Van Ierland, E. C. (2012). Tourist preferences for ecotourism in rural communities adjacent to kruger national park: A choice experiment approach. Tourism Management, 33(1), 168-176.

Champ, P. A., Boyle, K. J., \& Brown, T. C. (2017). A primer on nonmarket valuation (2nd ed.). Dordrecht: Springer.

Charities Aid Foundation. (2017). CAF UK giving 2017. An overview of charitable giving in the UK. West Malling: CAF.

Charities Aid Foundation. (2019). CAF world giving index (10 th ed.). West Malling: CAF. Ten years of giving trends.

Chen, B., Namaka, Y., \& Zhang, Y. (2017). Traditional village forest landscapes: Tourists' attitudes and preferences for conservation. Tourism Management, 59, 652-662.

Chen, M. F., \& Tung, P. J. (2014). Developing an extended theory of planned behavior model to predict consumers' intention to visit green hotels. International Journal of Hospitality Management, 36, 221-230.

ChoiceMetrics. (2014). Ngene 1.1.2 user manual \& reference guide.

Choi, A. S., \& Fielding, K. S. (2013). Environmental attitudes as WTP predictors: A case study involving endangered species. Ecological Economics, 89, 24-32.

Choi, A. S., Ritchie, B. W., Papandrea, F., \& Bennett, J. (2010). Economic valuation of cultural heritage sites: A choice modeling approach. Tourism Management, 31, 213-220.

Cooper, P., Poe, G. L., \& Bateman, I. J. (2004). The structure of motivation for contingent values: A case study of lake water quality improvement. Ecological Economics, 50(1), 69-82.

Coria, J., \& Calfucura, E. (2012). Ecotourism and the development of indigenous communities: The good, the bad, and the ugly. Ecological Economics, 73, 47-55.

Craigwell, R., \& Moore, W. (2008). Foreign direct investment and tourism in Sids: Evidence from panel causality tests. Tourism Analysis, 13(4), 427-432.

Cronbach, L. J. (1951). Coefficient alpha and the internal structure of tests. Psychometrika, 16, 297-334.

Das, M., \& Chatterjee, B. (2015). Ecotourism: A panacea or a predicament? Tourism Management Perspectives, 14, 3-16.

DeShazo, J. R., \& Fermo, G. (2000). Designing choice sets for stated preference methods: The effects of complexity on choice consistency. Journal of Environmental Economics and Management, 44(1), 123-143.

Dono, J., Webb, J., \& Richardson, B. (2010). The relationship between environmental activism, pro-environmental behaviour and social identity. Journal of Environmental Psychology, 30(2), 178-186.

Dunlap, R. E., \& Van Liere, K. D. (1978). The new environmental paradigm: A proposed measuring instrument and preliminary results. The Journal of Environmental Education, 9(4), 10-19.

Dunlap, R. E., Van Liere, K. D., Mertig, A. G., \& Jones, R. E. (2000). Measuring endorsement of the new ecological paradigm: A revised nep scale. Journal of Social Issues, 56(3), 425-442.
Edwards, P. E. T. (2009). Sustainable financing for ocean and coastal management in Jamaica: The potential for revenues from tourist user fees. Marine Policy, 33, 376-385.

Ferrini, S., \& Scarpa, R. (2007). Designs with a-priori information for nonmarket valuation with choice-experiments: A Monte Carlo study. Journal of Environmental Economics and Management, 53, 342-363.

Fifer, S., Rose, J., \& Greaves, S. (2014). Hypothetical bias in stated choice experiments: Is it a problem? And if so, how do we deal with it? Transportation Research Part A, 61, $164-177$.

Gössling, S. (2002). Global environmental consequences of tourism. Global Environmental Change, 12(4), 283-302.

Govan, H., Tawake, A., Tabunakawai, K., Jenkins, A., Lasgorceix, A., Techera, E., Tafea, H., Kinch, J., Feehely, J., Ifopo, P., \& Hills, R. (2009). Community conserved areas: A review of status \& needs in melanesia and polynesia. ICCA regional review for CENESTA/TILCEPA/TGER/IUCN/GEF-SGP.

Grilli, G., Notaro, S., \& Cambell, D. (2018). Including value orientations in choice models to estimate benefits of wildlife management policies. Ecological Economics, 151, $70-81$.

Hearne, R., \& Santos, C. (2005). Tourists' and locals' preferences toward ecotourism development in the Maya Biosphere Reserve, Guatemala. Environment, Development and Sustainability, 7(3), 303-318.

Hemker, B. T., Sijtsma, K., \& Molenaar, I. W. (1995). Selection of unidimensional scales from a multidimensional item bank in the polytomous Mokken IRT model. Applied Psychological Measurement, 19(4), 337-352.

Hensher, D. A. (2010). Hypothetical bias, choice experiments and willingness to pay. Transportation Research Part B: Methodological, 44(6), 735-752.

Hensher, D. A., \& Greene, W. H. (2003). The mixed logit model: The state of practice Transportation, 30(2), 133-176.

Hensher, D. A., Rose, J. M., \& Greene, W. H. (2005). Applied choice analysis: A primer. Cambridge: Cambridge University Press.

Hess, S., \& Beharry-Borg, N. (2012). Accounting for latent attitudes in willingness-to-pay studies: The case of coastal water quality improvements in Tobago. Environmental and Resource Economics, 52, 109-131.

Hess, S., Ben-Akiva, M., Dinesh, G., \& Walker, J. L. (2009). Taste heterogeneity, correlation, and elasticities in latent class choice models. Washington DC, United States: Transportation Research Board 88th Annual. Presented at 2009.

Hess, S., \& Daly, A. (2014). Handbook of choice modelling. Cheltenham: Edward Elgar.

Hole, A. R. (2006). CLOGITHET: Stata module to estimate heteroscedastic conditional logit models. Statistical Software Components S456737. Boston College Department of Economics.

Hong, S., Kim, J., \& Kim, S. (2003). Implications of potential green tourism development. Annals of Tourism Research, 30(2), 323-341.

Horton, B., Colarullo, G., Bateman, I. J., \& Peres, C. A. (2003). Evaluating non-user willingness to pay for a large-scale conservation programme in amazonia: A UK/ Italian contingent valuation study. Environmental Conservation, 30(2), 139-146.

Hoyos, D. (2010). The state of the art of environmental valuation with discrete choice experiments. Ecological Economics, 69, 1595-1603.

Hoyos, D., Mariel, P., \& Hess, S. (2015). Incorporating environmental attitudes in discrete choice models: An exploration of the utility of the awareness of consequences scale. The Science of the Total Environment, 505, 1100-1111.

Hu, L., \& Bentler, P. M. (1999). Cut-off criteria for fit indexes in covariance structure analysis: Conventional criteria versus new alternatives. Structural Equation Modelling, 6, 1-55.

Hultman, M., Kazeminia, A., \& Ghasemi, V. (2015). Intention to visit and willingness to pay premium for ecotourism: The impact of attitude, materialism, and motivation. Journal of Business Research, 68(9), 1854-1861.

Huybers, T., \& Bennett, J. (2000). Impact of the environment on holiday destination choices of prospective UK tourist: Implications for tropical North Queensland. Tourism Economics, 6, 21-46.

Iranah, P., Lal, P., Wolde, B. T., \& Burli, P. (2018). Valuing visitor access to forested areas and exploring willingness to pay for forest conservation and restoration finance: The case of small island developing state of Mauritius. Journal of Environmental Management, 223, 868-877.

Johnston, R. J., Boyle, K. J., Adamowicz, W., Bennett, J., Brouwer, R., Cameron, T. A., Hanemann, W. M., Hanley, N., Ryan, M., Scarpa, R., Tourangeau, R., \& Vossler, C. A. (2017). Contemporary guidance for stated preference studies. Journal of the Association of Environmental and Resource Economists, 4(2), 319-405.

Kaiser, F. G., \& Wilson, M. (2004). Goal-directed conservation behavior: The specific composition of a general performance. Personality and Individual Differences, 36(7), 1531-1544.

Kelly, J., Haider, W., Williams, P. W., \& Englond, K. (2007). Stated preferences of tourists for eco-efficient destination planning options. Tourism Management, 28, 377-390.

Kerstetter, D., \& Bricker, K. (2009). Exploring Fijian's sense of place after exposure to tourism development. Journal of Sustainable Tourism, 17(6), 691-708.

Kim, S. S., Wong, K. K. F., \& Cho, M. (2007). Assessing the economic value of a world heritage site and willingness-to-pay determinants: A case of changdeok palace. Tourism Management, 28, 317-322.

Kline, R. B. (2010). Principles and practice of structural equation modelling (3rd ed.). New York: Guilford Press.

Kontoleon, A., \& Swanson, T. (2003). The willingness to pay for property rights for the giant panda: Can a charismatic species be an instrument for nature conservation? Land Economics, 79(4), 483-499. 
Kramer, R. A., \& Mercer, D. E. (1997). Valuing a global environmental good: US residents' willingness to pay to protect tropical rain forests. Land Economics, 196-210.

Lee, D. E., \& Du Preez, M. (2016). Determining visitor preferences for rhinoceros conservation management at private, ecotourism game reserves in the eastern cape province, South Africa: A choice modeling experiment. Ecological Economics, 130, 106-116.

León, C. J., de León, J., Araña, J. E., \& González, M. M. (2015). Tourists' preferences for congestion, residents' welfare and the ecosystems in a national park. Ecological Economics, 118, 21-29.

Lindhjem, H., \& Navrud, S. (2011). Are Internet surveys an alternative to face-to-face interviews in contingent valuation? Ecological Economics, 70(9), 1628-1637.

Loevinger, J. (1948). The technique of homogeneous tests compared with some aspects of "scale analysis" and factor analysis. Psychological Bulletin, 45, 507-530.

Mangubhai, S., Sykes, H., Manley, M., Vukikomoala, K., \& Beattie, M. (2020). Contributions of tourism-based Marine Conservation Agreements to natural resource management in Fiji. Ecological Economics, 171, 106607. May 2020.

McFadden, D. (1974). Conditional logit analysis of qualitative choice behavior. In P. Zarembka (Ed.), Frontiers in econometrics. New York: Academic Press.

Morse-Jones, S., Bateman, I. J., Kontoleon, A., Ferrini, S., Burgess, N. D., \& Turner, R. K. (2012). Stated preferences for tropical wildlife conservation amongst distant beneficiaries: Charisma, endemism, scope and substitution effects. Ecological Economics, 78, 9-18.

Naidoo, R., \& Adamowicz, W. L. (2005). Biodiversity and nature-based tourism at forest reserves in Uganda. Environment and Development Economics, 10(2), 159-178.

Narayan, P. K., Narayan, S., Prasad, A., \& Prasad, B. C. (2010). Tourism and economic growth: A panel data analysis for pacific island countries. Tourism Economics, 16(1), $169-183$.

U. Nation. (2014). A/RES/69/15 - SIDS accelerated Modalities of action (Samoa) pathway. Third international conference on small island developing States (SIDS conference), 1-4 september 2014. Samoa: Apia.

Navrud, S., \& Strand, J. (2018). Valuing global ecosystem services: What do European experts say? Applying the delphi method to contingent valuation of the amazon rainforest. Environmental and Resource Economics, 70, 249-269.

Neto, F. (2003). A new approach to sustainable tourism development: Moving beyond environmental protection. In Natural resources forum (Vol. 27, pp. 212-222). Blackwell Publishing Ltd. No. 3.

Nunnally, J. C., \& Bernstein, I. H. (1994). Psychometric theory (3rd ed.). New York: McGraw-Hill.

Office for National Statistics. (2017). People, population and community (p. 18) Accessed 291.

Olsen, S. B. (2009). Choosing between internet and mail survey modes for choice experiments surveys considering non-market goods. Environmental and Resource Economics, 44, 591-610.

Pacifico, D., \& Yoo, H. (2013). LCLOGIT: A Stata command for fitting latent-class conditional logit models via the expectation-maximization algorithm. STATA Journal, 13(3), 625-639.

Pakalniete, K., Aigars, J., Czajkowski, M., Strake, S., Zawojska, E., \& Hanley, N. (2017) Understanding the distribution of economic benefits from improving coastal and marine ecosystems. The Science of the Total Environment, 584, 29-40.

Pan, S. Y., Mengyao, G., Kim, H., Shah, K. J., Pei, S. L., \& Chiang, P. C. (2018). Advances and challenges in sustainable tourism toward a green economy. The Science of the Total Environment, 635, 452-469.

Pratt, S. (2015). The economic impact of tourism in SIDS. Annals of Tourism Research, 52, $148-160$.

Pratt, S., McCabe, S., \& Movono, A. (2016). Gross happiness of a 'tourism' village in Fiji. Journal of Destination Marketing \& Management, 5, 26-35.

Rolfe, J., Bennett, J., \& Louviere, J. (2000). Choice modelling and its potential application to tropical rainforest preservation. Ecological Economics, 35(2), 289-302.

Ruhanen, L., Weiler, B., Moyle, B. D., \& McLennan, C. J. (2015). Trends and patterns in sustainable tourism research: A 25-year bibliometric analysis. Journal of Sustainable Tourism, 23(4), 517-535.

Scandurra, G., Romano, A. A., Ronghi, M., \& Carfora, A. (2018). On the vulnerability of small island developing States: A dynamic analysis. Ecological Indicators, 84, 382-392.

Scarpa, R., \& Rose, J. M. (2008). Design efficiency for non-market valuation with choice modelling: How to measure it, what to report and why. The Australian Journal of Agricultural and Resource Economics, 52(3), 253-282.

Schubert, S. F., Brida, J. G., \& Risso, W. A. (2011). The impacts of international tourism demand on economic growth of small economies dependent on tourism. Tourism Management, 32(2), 377-385.

Seetanah, B. (2011). Assessing the dynamic economic impact of tourism for island economies. Annals of Tourism Research, 38(1), 291-308.

Sharpley, R. (2014). Host perceptions of tourism: A review of the research. Tourism Management, 42(1), 37-49.

StataCorp. (2017). Stata base reference manual (Vol. 15). Release.

Svedsäter, H. (2000). Contingent valuation of global environmental resources: Test of perfect and regular embedding. Journal of Economic Psychology, 21(6), 605-623.

Swanson, T., \& Kontoleon, A. (2004). Conflicts in wildlife conservation: Aggregating total economic values. In P. Kondouri (Ed.), Econometrics informing natural resources management. Edward Elgar Publishing.

Train, K. E. (2009). Discrete choice methods with simulation (2nd ed.). Cambridge: Cambridge University Press.

United Nations. (2015). Transforming our world: The 2030 agenda for sustainable development A/RES/70/1. https://sustainabledevelopment.un.org/post2015/transfo rmingourworld/publication.
United Nations Development Programme. (2015). Financing for development and small island development States: A snapshot and ways forward. New York: UNDP.

United Nations Environment Programme. (2014). Emerging issues for small island developing States. Results of the UNEP foresight process. Nairobi, Kenya: UNEP.

United Nations Environment Programme and World Tourism Organization. (2005). Making tourism more sustainable. A guide for policy makers. Paris and Madrid: UNEP and UNWTO.

do Valle, P. O., Pintassilgo, P., Matias, A., \& André, F. (2012). Tourist attitudes towards an accommodation tax earmarked for environmental protection: A survey in the algarve. Tourism Management, 33, 1408-1416.

Windle, J., \& Rolfe, J. (2011). Comparing responses from internet and paper-based collection methods in more complex stated preference environmental valuation surveys. Economic Analysis and Policy, 41(1), 83-97.

Witter, M. (2011). Financing sustainable development in small island developing States. In C. Vigilance, \& J. L. Roberts (Eds.), Tools for mainstreaming sustainable development in small States. London: Commonwealth Secretariat.

Woo, E., Kim, H., \& Uysal, M. (2015). Life satisfaction and support for tourism development. Annals of Tourism Research, 50, 84-97.

World Tourism Organization. (1997). Agenda 21 for the travel and tourism industry: Towards environmentally sustainable development. Madrid: UNWTO.

World Tourism Organization. (2012). Challenges and opportunities for tourism development in small island developing States. Madrid: UNWTO.

World Tourism Organization. (2020). Yearbook of tourism statistics, data 2014 - 2018 (2020 Edition). Madrid: UNWTO.

World Tourism Organization and United Nations Development Programme. (2017). Tourism and the sustainable development Goals - journey to 2030. Madrid: UNWTO.

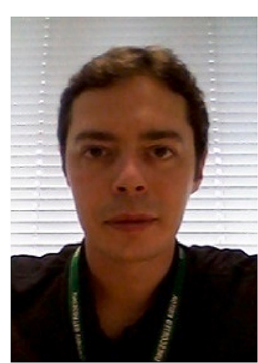

Gaetano Grilli is an applied economist specialised in quantitative methods for environmental and social research. He is interested in the relationships between ecosystem services and individual well-being, focusing on environmental valuation, applied microeconomics, and quality-of-life.

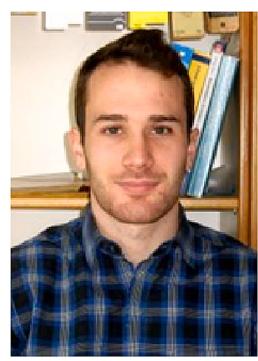

Emmanouil Tyllianakis is an environmental economist. His work moves along these two research lines: 1) Understanding how human behaviour impacts water ecosystems and human welfare in return and 2) Capturing the implications of climate change and how nature-based solutions can mitigate them and how this can be linked to perceptions.

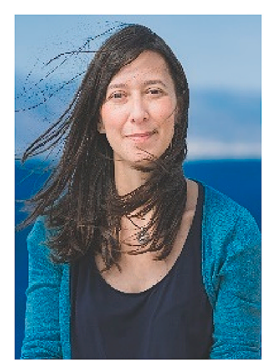

Tiziana Luisetti is a senior environmental economist with over ten-year research experience specialised in coastal and marine ecosystem services valuation and management, and recently working on natural capital accounting. 


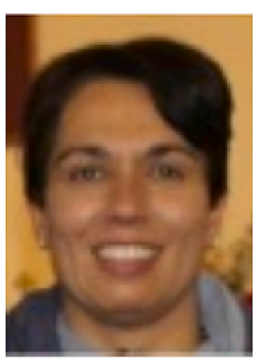

Silvia Ferrini is an applied economics with a long track record of research experience. Her research interests are applied economics, non-market evaluation methods, discrete choice models and experimental design techniques.

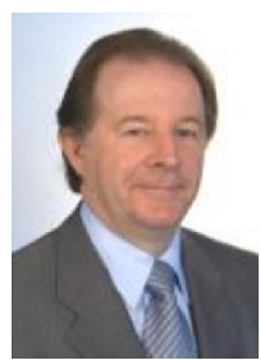

R. Kerry Turner specialises in environmental economics, coastal zone and wetland management, conservation economics and waste management research. He has published widely ( $>300$ publications) on these subjects including a number of best-selling texts. 